\title{
Procedure Success Indicator
}

National Cancer Institute

\section{Source}

National Cancer Institute. Procedure Success Indicator. NCI Thesaurus. Code C119240.

An indication as to whether the procedure is considered successful. 